\title{
HTERT I540/R572Y/D988Y Multipeptide Vaccine
}

National Cancer Institute

\section{Source}

National Cancer Institute. hTERT 1540/R572Y/D988Y Multipeptide Vaccine. NCI

Thesaurus. Code C71761.

A peptide vaccine consisting of multiple epitopes derived from the human telomerase reverse transcriptase (hTERT), the catalytic subunit of human telomerase, with potential immunostimulating and antineoplastic activities. hT ERT I540/R572Y/D988Y multipeptide vaccine contains strongly antigenic peptide epitopes I540 (9-mer), R572Y (9-mer) and D988Y (10-mer). Vaccination with this agent may elicit a cytotoxic T cell (CTL) response against telomerase-expressing tumor cells. Directly linked to tumorigenesis, telomerase is expressed in the majority of human cancer cells but is infrequently expressed in normal cells. 